\title{
Buried, Viable Seeds and Their Relation to Revegetation after Surface Mining
}

\author{
LOUIS R. IVERSON AND MOHAN K. WALI
}

\begin{abstract}
The quantity and quality of seeds present in prairie soils prior to surface mining were determined in this study. Samples were collected near Beulah in western North Dakota from 4 sites (1 each from grazed and ungrazed areas, 1-yea rold stockpiled topsoil, and a fresh stockpile). Samples were taken from 3 depths and allowed to germinate in a growth chamber for 16 months. The grazed site had a seed density of over 7,700 seeds $\mathrm{m}^{2}$ ( $43 \%$ were from weed species), and the ungrazed site had 3,900 seeds $\mathrm{m}^{-2}$ (7\% were weeds); the stockpiled topsoils had very low seed densities. Seed density and diversity decreased with depth on both the grazed and ungrazed sites; this was especially true for the grazed site where $94 \%$ of the seeds were found in the top $7.5 \mathrm{~cm}$. Comparisons were made between the seed banks and the aboveground vegetation of the unmined site and 4 mined sites (ages 1-4 years after reclamation). Analysis indicated that seeds of the most prevalent colonizers after reclamation [e.g. summer cypress (Kochia scoparia), green pigeongrass (Setaria viridis), and Russian thistle (Salsola collina)] were not present in the topsoil; rather, they immigrated from the surrounding areas. Several species which were present in the seed bank [e.g. rough penny royal (Hedeoma hispida), buckhorn (Plantago patagonica), white sage (Artemisia ludoviciana), fringed sage $(A$. frigida), and wormwood $(A$. absinthium)] were found in the aboveground vegetation of 3-and 4-year-old mined sites, and at the unmined site. Evidence from seed banks and extant aboveground vegetation suggests that both seed dispersal in time (dormancy) and dispersal in space (immigration) are important in determining the type of vegetation on mined areas after topsoil has been replaced.
\end{abstract}

The vegetation that emerges following currently mandated mined land reclamation practices (viz., contouring, replacing topsoil, fertilizing, and seeding), is determined not only by the planted seed mix, but also by the seed stock (seed bank) present in the topsoil and the immigration of seeds and disseminules from neighboring ecosystems. It is, therefore, important to determine the kinds of species and quantity of viable seeds in the topsoil prior to mining. Such information would be of value in evaluating the potential of topsoil to determine the initial course of succession on these sites.

Several factors determine the quantity and quality of seed banks: (1) reproductive potential of plants; (2) dispersal mechanisms; (3) dormancy patterns; (4) characteristics of the soil; (5) biotic influences, i.e. predation and decomposition; (6) weather fluctuations; and (7) disturbances to the soil surface (Thurston 1960, Barton 1962). It has been noted that disrupting the soil surface often breaks seed dormancy by exposing seeds to unfiltered light, fluctuating temperatures, and reduced $\mathrm{CO}_{2}$ concentrations (Bazzaz

The authors are postdoctoral research associate, Project Reclamation, and director, Project Reclamation and professor of biology, respectively, at the University of North Dakota, Grand Forks 58202.

This research was supported by a National Science Foundation Energy Traineeship to L.R.I., and by Grant No. G026400I and Contract No. J0295015 from the U.S. Department of the Interior-Bureau of Mines to M.K.W. The authors are indebted to Dr. Stuart Nicholson and Mr. Richard H. Bares for useful comments on the manuscript, and Ms. Laura Brophy and Ms. Diana Schimmelpiennig For technical assistance.

Manuscript received December 20, 1981
1970, 1979). Therefore, variations in methods and duration of removing, stockpiling, and respreading of topsoil during surface mining assume significance.

Several seed bank studies have been conducted to ascertain means of removing weedy seeds from arable agricultural soils. Major studies are from the British Isles (Brenchley and Warington 1930, 1933, 1936, 1945; Brenchley 1944; Roberts 1963, 1968; Roberts and Neilson 1981), Denmark (Jensen 1969), Saskatchewan (Chepil 1946, Budd et al. 1954), and from Minnesota (Robinson 1949). Pasture soils have been examined for weeds in Wales (Chippindale and Milton 1934, Milton 1948), and in New Hampshire (Prince and Hodgdon 1946). But seed bank studies in grasslands of the North American Great Plains are limited. In Kansas, Lippert and Hopkins (1950) studied native mixed grass and short grass prairies, an abandoned field, and a denuded pasture. Rabinowitz (1981) studied the seed bank and seed rain on a tall grass prairie in Missouri. Johnston et al. (1968) studied rangelands in Alberta for seed populations of mixed grass prairie and fescue grasslands including sites that ranged from ungrazed to heavily grazed. Dwyer and Aguirre (1978) determined germinable seed populations for 2 range condition classes on the Desert Grassland in New Mexico. Only a few seed bank studies in relation to surface mined land reclamation are available. Beauchamp et al. (1975) studied Wyoming sagebrush-grass topsoils as a potential seed source for re-seeding mined spoils, and Brophy (1980) studied viable seed populations in soils of revegetated North Dakota coal mines. Results of some of the above-mentioned studies have been tabulated (Table 1).

In the present study, we (1) estimate the viable seed populations in the native topsoil prior to mining in western North Dakota, and (2) compare the relative contributions of seed bank populations to seed populations migrating from surrounding areas as they determine the initial vegetation of mined areas.

\section{Procedures}

Two sites, one ungrazed, the other moderately to heavily grazed, on native mixed grass prairie (Whitman and Wali 1975) adjacent to active mining sites, were sampled in April, 1979 for estimation of buried seed populations. These sites, located $4.5 \mathrm{~km}$ south of Beulah, North Dakota, were typical pre-mined areas in western North Dakota which, during the mining process, have the topsoil and subsoil removed separately (up to a total of $1.5 \mathrm{~m} \mathrm{depth}$ ). The topsoil is then stockpiled while the overburden and coal are removed; after removal of coal, the areas are backfilled, recontoured, and the topsoil replaced. A total of 50 randomly placed, 5-cm diameter cores were taken from each site to provide 10-20 replicate samples representing the surface $2.5 \mathrm{~cm}$, top $7.5 \mathrm{~cm}$, and $7.5-15 \mathrm{~cm}$ depths. Eighteen replicate samples were also taken from each of the 2 nearby topsoil stockpiles: one stockpiled a year previously, the other only a week prior to sampling.

Samples were collected in airtight bags, transported to the laboratory, and stored at $4^{\circ} \mathrm{C}$ for $\mathrm{I}$ month. Storage at this temperature prevented seed germination but may have aided in the vernalization of seeds. 
Table 1. Seed density in seed banks of diverse community types.

\begin{tabular}{|c|c|c|c|c|}
\hline Investigation & Study site & Depth, cm & Total seeds $/ \mathrm{m}^{2}$ & Method \\
\hline $\begin{array}{l}\text { Iverson and Wali } \\
\text { (this study) }\end{array}$ & $\begin{array}{l}\text { North Dakota prairie } \\
\text { grazed site, mixed grass } \\
\text { ungrazed site, mixed grass }\end{array}$ & $\begin{array}{l}0-15 \\
0-15\end{array}$ & $\begin{array}{l}7740 \\
3870\end{array}$ & $\begin{array}{l}\text { Germination from cores for } 16 \\
\text { months. }\end{array}$ \\
\hline Brophy (1980) & $\begin{array}{l}\text { ungrazed mixed grass prairie } \\
\text { 6-year-old mined site }\end{array}$ & $\begin{array}{l}0-7.5 \\
0-7.5\end{array}$ & $\begin{array}{r}990 \\
2460\end{array}$ & $\begin{array}{l}\text { Washing/tetrazolium. } \\
\text { Washing/tetrazolium. }\end{array}$ \\
\hline Lippert and Hopkins (1950) & $\begin{array}{l}\text { Kansas } \\
\text { grazed mixed grass prairie } \\
\text { overgrazed short grass prairie } \\
\text { grazed short grass prairie } \\
25 \text {-year-old abandoned field }\end{array}$ & $\begin{array}{l}0-1.25 \\
0-1.25 \\
0-1.25 \\
0-1.25\end{array}$ & $\begin{array}{r}440 \\
3640 \\
760 \\
5130\end{array}$ & $\begin{array}{l}\text { Germination in boxes } \\
\text { from } 930 \mathrm{~cm}^{2} \text { samples } \\
\text { for } 76 \text { days. }\end{array}$ \\
\hline Johnston et al. (1968) & $\begin{array}{l}\text { Alberta } \\
\text { ungrazed rangeland } \\
\text { heavily grazed rangeland }\end{array}$ & $\begin{array}{l}0-2.5 \\
0-2.5\end{array}$ & $\begin{array}{l}2970 \\
3240\end{array}$ & $\begin{array}{l}\text { Germination from cores } \\
\text { for } 3 \text { weeks. }\end{array}$ \\
\hline Beuchamp et al. (1975) & $\begin{array}{l}\text { Wyoming } \\
\text { sagebrush grass }\end{array}$ & $0-5$ & 370 & $\begin{array}{l}\text { Germination in flats } \\
\text { from } 100 \mathrm{~cm}^{2} \text { samples for } 6 \text { weeks. }\end{array}$ \\
\hline Rabinowitz (1980) & $\begin{array}{l}\text { Missouri } \\
\quad \text { tall grass prairie }\end{array}$ & $0-12$ & 6470 & $\begin{array}{l}\text { Germination from cores for } \\
145 \text { days. }\end{array}$ \\
\hline Dwyer and Aguirre (1978) & $\begin{array}{l}\text { New Mexico Desert Grassland } \\
\text { poor range } \\
\text { fair range } \\
\text { good range }\end{array}$ & $\begin{array}{l}0-2 \\
0-2 \\
0-2\end{array}$ & $\begin{array}{l}485 \\
810 \\
285\end{array}$ & $\begin{array}{l}\text { Germination from cores for } \\
2 \text { months }\end{array}$ \\
\hline Major and Pyott (1966) & $\begin{array}{l}\text { California } \\
\text { ungrazed bunchgrass } \\
\text { grazed bunchgrass }\end{array}$ & $\begin{array}{l}0-5 \\
0-5\end{array}$ & $\begin{array}{r}8230 \\
12,290\end{array}$ & $\begin{array}{l}\text { Germination from cores } \\
\text { for } 6 \text { months }\end{array}$ \\
\hline Robinson (1949) & $\begin{array}{l}\text { Minnesota } \\
\text { cropland }\end{array}$ & $0-15$ & 8300 & Germination from cores. \\
\hline Roberts (1963) & $\begin{array}{l}\text { England } \\
\text { arable land }\end{array}$ & $0-10$ & 8600 & Germination from cores for 2 years. \\
\hline Jensen (1969) & $\begin{array}{l}\text { Denmark } \\
\text { arable land }\end{array}$ & $0-20$ & 19,240 & $\begin{array}{l}\text { Germination from cores for } \\
23 \text { months. }\end{array}$ \\
\hline
\end{tabular}

Each of 136 samples were treated as follows: $50 \mathrm{~g}$ of dry sterilized peat (for water retention) were placed in a 0.5 liter container, covered with a filter paper on which $100 \mathrm{~g}$ of field sample was placed. The containers were kept moist with deionized water throughout the 16-month duration of the experiment. The growth chamber conditions were $15 \mathrm{hr}$ day $/ 9 \mathrm{hr}$ night length, $26^{\circ} \mathrm{C}$ day $/ 18^{\circ}$ night temperature, and 54-72 microeinsteins $\mathrm{m}^{-2} \mathrm{sec}^{-1}$ photosynthetically active radiation. These environmental conditions are known to be favorable for germination for a wide range of species. Plants were identified as early in their life cycle as possible, and removed promptly after identification. Seedlings were identified following Dunham et al. (1947), Gleason and Cronquist (1963), Stevens (1963), Best et al. (1971), and Van Bruggen (1976).

The experiment was monitored and the data were grouped by 4 time periods: seedling emergence during (a) initial 4 months of the experiment, May-August 1979 (hereafter period 'A'); SeptemberDecember 1979 (period 'B'); January-April 1980 (period 'C'); and May-September 1980 (period 'D').

Statistical analysis included calculation of seed density means with $95 \%$ confidence intervals both for site and depth, and $t$-tests for detecting differences between sites. In addition, ShannonWeiner index of diversity values were calculated.

\section{Results and Discussion}

\section{Seed Numbers}

From the grazed site samples, a total of 319 seedlings ( 26 species) germinated during the 16-month study period (Fig. 1); $46 \%$ of the seedlings were horseweed (Conyza canadensis), six-weeks fescue (Festuca octoflora), and rough penny royal. In contrast, significantly fewer $(P<.01)$ seedlings (140) representing 23 species emerged from the ungrazed site samples with green sage (Artemisia dracunculus), yellow sweet clover (Melilotus officinalis), and blue grama (Bouteloua gracilis) accounting for $52 \%$ of the total (Fig. 2; Table 2). Numbers of germinating seeds in both fresh and 1-year old stockpiled topsoils were very low and significantly fewer $(P<.01)$ than the grazed or ungrazed sites; only 14 seedlings from 9 species emerged (Table 2). Blue grama and six-weeks fescue were the only 2 species common to both topsoils; little bluestem (Andropogon scoparius) and ticklegrass (Agrostis scabra) were present only in the fresh stockpile. The paucity of seeds in the stockpiled topsoil (also reported by Brophy 1980) may be due to the inversion of soil layers during the stockpiling process whe rein upper layers are buried deep while the lower layers are placed on top. Seeds may also lose viability over time during stockpiling.

In contrast to the ungrazed site, the grazed site not only had statistically higher seed numbers, but also a high proportion of weed seeds ( $44 \%$ as against $7 \%$ ). Our results show a similar trend to that of Lippert and Hopkins (1950) who found the seed bank in an overgrazed shortgrass prairie in Kansas composed of $85 \%$ weed seeds, compared with $58 \%$ weed seeds in a moderately grazed site. The presence of larger numbers of weed seeds after grazing may be attributed to (1) the avoidance of weeds by grazers, and (2) a greater seed output by weeds (ruderal-selected species of Grime 1979). These data indicate that notice should be taken as to the grazing history on pre-mined sites, as it has a bearing on the initial aboveground flora.

\section{Distribution by Depth}

On both grazed and ungrazed sites, the surface layers had the highest concentrations of seeds; seed quantity and diversity diminished with depth (Table 2). Seeds are moved to lower depths by physical means such as washing down fissures and by biotic activity such as the storage of seeds by insects or earthworm burrowing 


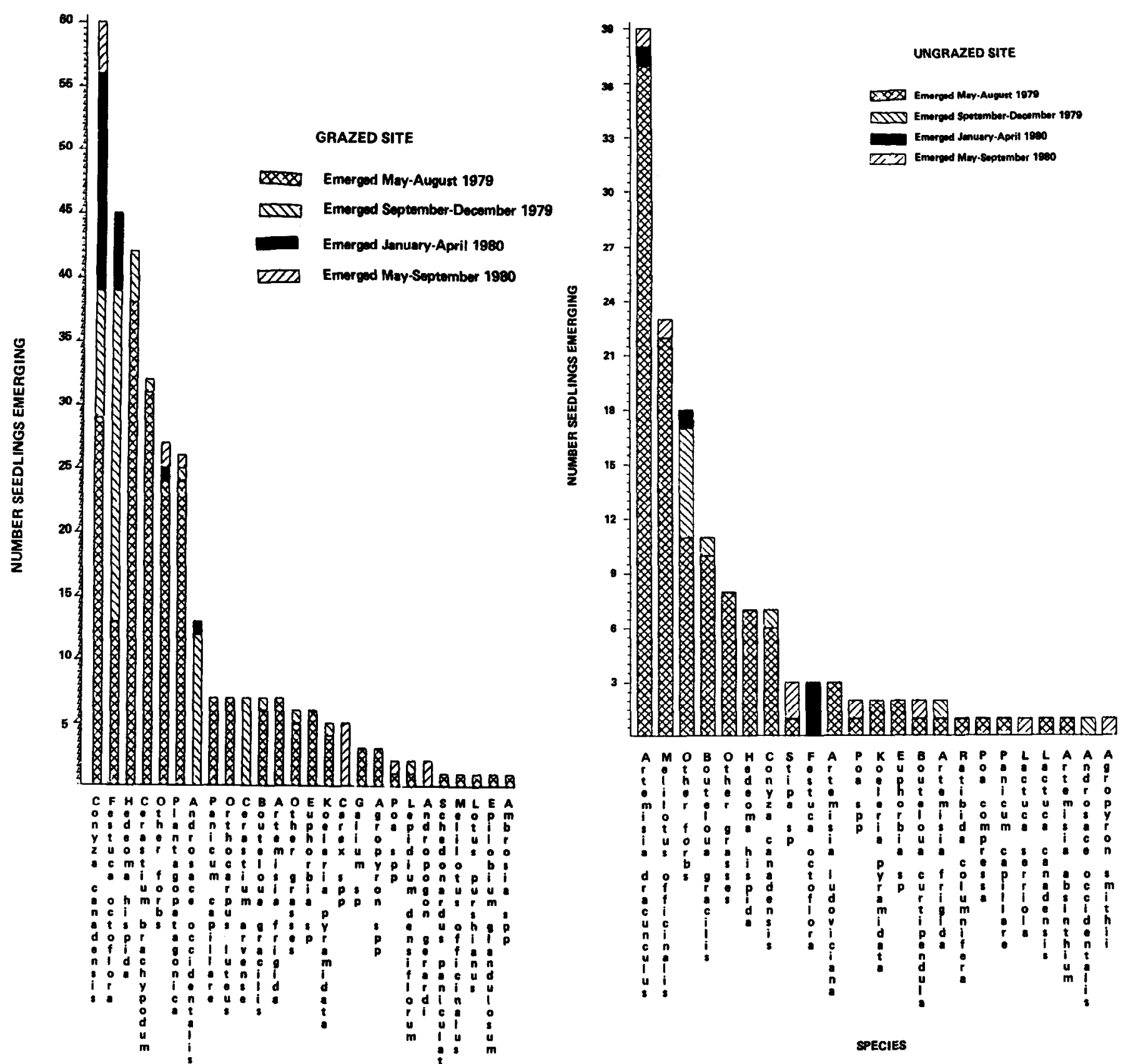

Fig. 2. Numbers of seedlings emerging from ungrazed site samples for each of 23 species types over 4 time periods.

SPECIES

Fig. 1. Numbers of seedlings emerging from grazed site samples for each of 26 species types over 4 time periods.

(McRill and Sagar 1973, Mortimer 1974). About $94 \%$ of the seeds at the grazed site were in the top $7.5 \mathrm{~cm}$ compared with $74 \%$ seeds in the same layer on the ungrazed site (Figs. 3, 4). The paucity of seeds found in the deeper layer $(7.5-15 \mathrm{~cm})$ at the grazed site may be the result of increased compaction of soils from trampling and the consequent decrease in the number of fissures for seed transport. Major and Pyott (1966) also found a higher proportion of seeds at the surface of a grazed site in California. Again, decreasing seed diversity with depth may be due to compaction with only the small seeded species (i.e., yellow sweetclover, six-weeks fescue, horseweed) penetrating to the $7.5-15 \mathrm{~cm}$ depth.

\section{Time of Emergence}

Most seedlings emerged during the first 4 months of the experi-

ment: $61 \%$ from the grazed samples, $71 \%$ from the ungrazed (Fig. $3,4)$. This should be expected since most seeds have dormancy periods of less than 4 months when conditions are favorable for germination. The 2 species that germinated most frequently after the first 4 months were horseweed and six-weeks fescue (Fig. 1, 2), both of which were found most frequently in the lowest depth. This suggests that seeds with long dormancy periods have greater propensity for survival at greater depths than do seeds with short dormancy periods.

\section{Comparison with Previous Studies}

Our data fall well within the range reported by other workers (Table 1): Dwyer and Aguirre (1978) reported a seed density of only 285 seeds $\mathrm{m}^{-2}$ on good condition Desert Grassland range in New Mexico whereas Jensen (1969) found up to 19,240 seeds $\mathrm{m}^{-2}$ in a Denmark cultivated field. Differences among sites may be attributed to differences in community types, field conditions, sampling methodologies, and duration of the experiments. In general, culti- 


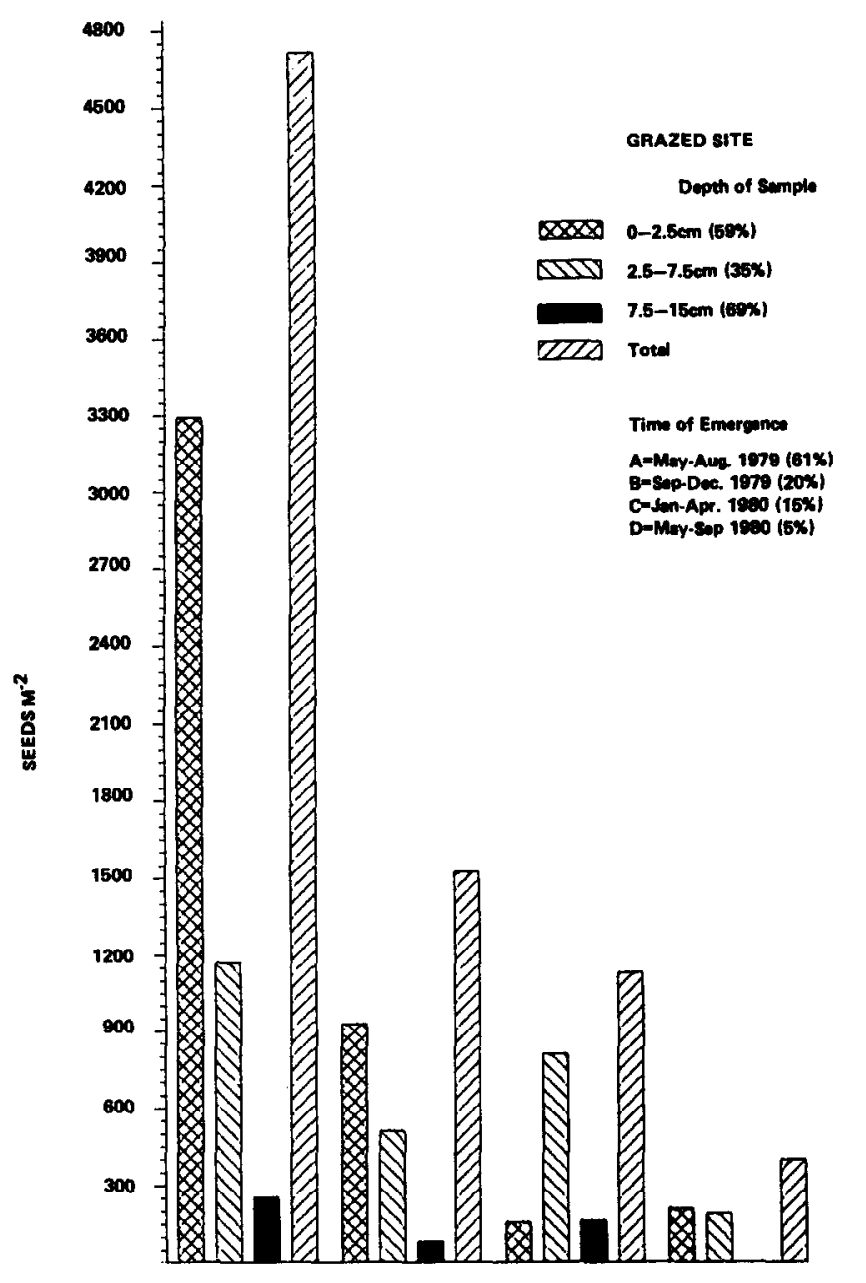

$\longmapsto A \longmapsto B \longrightarrow$ -

Fig. 3. Total seedlings emerging $m^{-2}$ from grazed site samples at 3 depths over 4 time periods.

vated and grazed areas tend to have the largest seed concentrations, most of which belong to weeds. Based on these data, numbers of buried viable seeds in North American undisturbed grasslands apparently decrease from the tall grass to the desert grass prairies.

\section{Role in Revegetation}

Comparison of the species composition of the seed bank to that of the above-ground vegetation of newly reclaimed surface mined areas (see Iverson 1981, Iverson and Wali 1982) reveals that species dispersal in time (through dormancy) as well as dispersal in space (through immigration) are important in revegetation. Pioneering species common to both aboveground vegetation and the seed bank included horseweed, witchgrass (Panicum capillare), prickly lettuce (Lactuca serriola), peppergrass (Lepidium densiflorum), bluegrass (Poa sp.), and ragweed (Ambrosia sp.). However, in the first 2 years of succession, dispersal in space seems to predominate, for none of the following dominant aboveground species were found in the seed bank: summer cypress, green pigeongrass, and Russian thistle (Iverson and Wali 1982). Chepil (1946) investigated dormancy lengths for a number of weedy species in Saskatchewan and found summer cypress sends to have a short dormancy period (2-3 months) and Russian thistle and green pigeongrass to have dormancies of less than one year. The absence of some colonizers in the seed bank that are dominant in the aboveground vegetation indicates that their seeds arrive after the respreading of topsoil; wind and water dispersal seem to be the most important, especially for the "tumbleweed" chenopods.

However, there is evidence that spreading topsoil is beneficial

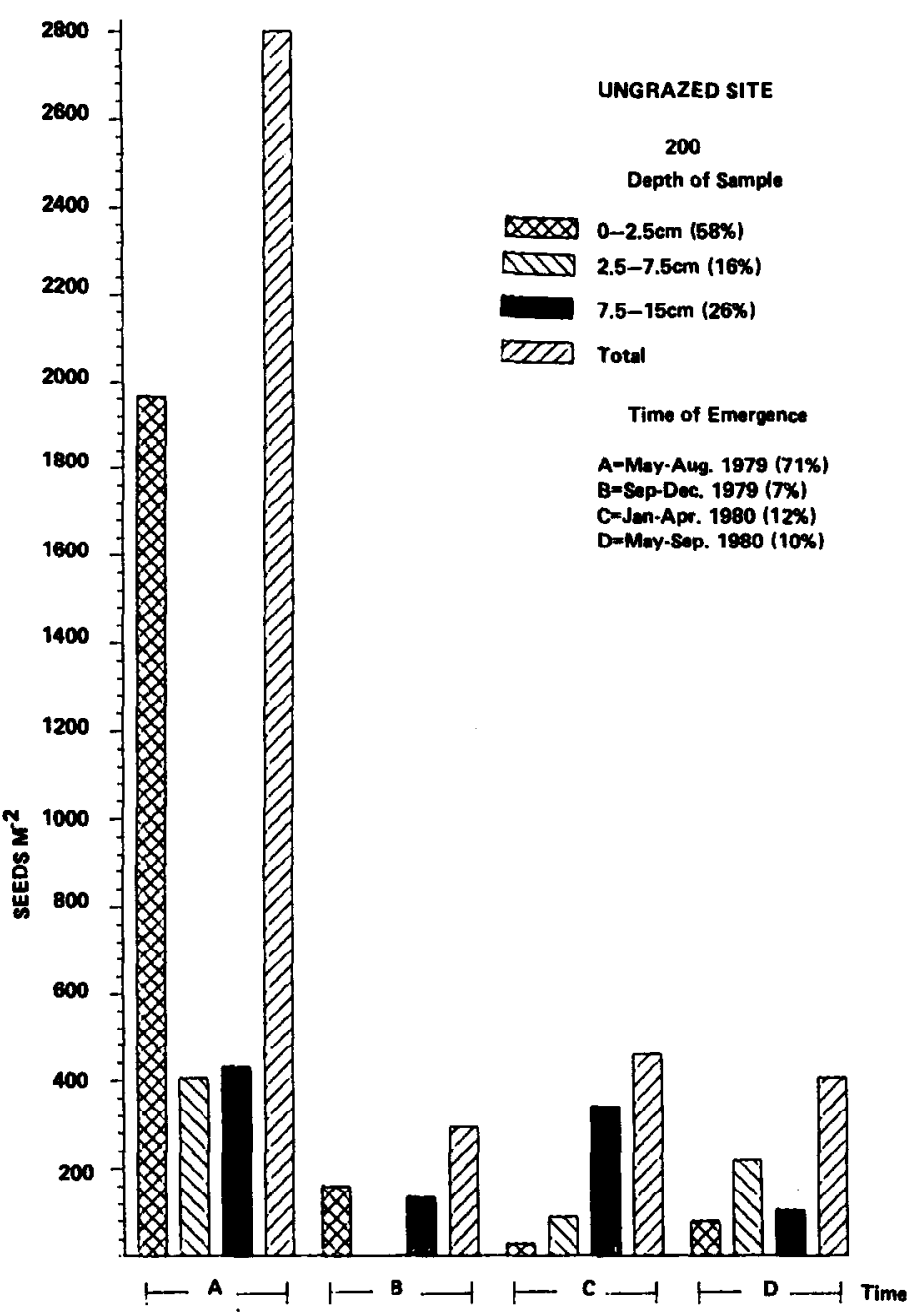

Fig. 4. Total seedlings emerging $m^{-2}$ from ungrazed site samples at 3 depths over 4 time periods.

for reintroducing some species which otherwise do not colonize readily. Species such as rough penny royal, buckhorn, white sage, fringed sage, and wormwood were present both in at least one of the seed banks (Fig. 1,2) and in the 4-year post-mining vegetation (Iverson and Wali 1982). It may be that some seeds from such species were lying dormant in the seed bank until establishment was possible (see Thompson and Grime 1979). The seed bank also contained seeds from 9 species found only on unmined sites in the vegetation survey. (Fig. 1, 2; Iverson and Wali 1982). It is not known whether these seeds remain viable in the soil for more than 4 years; if they do germinate at a later date, the diversity of the aboveground vegetation would be enhanced, a desired goal in reclamation. Evidence from Dr. W.J. Beal's experiments(Darlington 1931, 1941), and others, indicates that seeds frequently remain viable for more than 4 years. Along with aiding in amelioration of water-holding capacity and nutrient concentrations, topsoil spreading during the reclamation process may increase seed and consequently plant diversity. As the surface $7.5 \mathrm{~cm}$ contains the greatest proportion of seeds, (Table 2 ) it would be ideal if this layer from the premined areas could be placed on top of the post-mined areas.

Recent studies on succession (Connell and Slatyer 1977, Noble and Slatyer 1980) point to the key role of seed and propagule dissemination in community dynamics. From this study, it appears that the seed bank of the pre-mined prairie sites influences the post-mined vegetation in later stages via persistent seeds (dispersal in time), whereas seeds of most of the initial colonizers after reclamation immigrate from the surrounding environs (dispersal in space) after the topsoil is respread. 
Table 2. Seed density and diversity in the seed banks from ungrazed and grazed prairie, and 2 topsoil stockpiles in western North Dakota.

\begin{tabular}{|c|c|c|c|c|c|c|c|}
\hline \multirow[b]{2}{*}{ Site } & \multirow{2}{*}{$\begin{array}{c}\text { Depth } \\
(\mathrm{cm})\end{array}$} & \multicolumn{3}{|c|}{ Germinable seeds $\mathrm{m}^{-2}$} & \multirow{2}{*}{$\begin{array}{l}\text { Seed } \\
\text { diversity }\end{array}$} & \multirow{2}{*}{$\begin{array}{c}\text { Important species } \\
\text { P5\% of total) }\end{array}$} & \multirow{2}{*}{$\begin{array}{l}\% \text { of } \\
\text { total } \\
\end{array}$} \\
\hline & & Mean & $95 \%$ confiden & & & & \\
\hline Ungrazed & $\begin{array}{c}0-2.5 \\
0-7.5 \\
* 2.5-7.5 \\
7.5-15\end{array}$ & $\begin{array}{c}2235+ \\
2980+ \\
745+ \\
1005\end{array}$ & $\begin{array}{r}1465-3000 \\
1960-4005 \\
60-1950\end{array}$ & $\begin{array}{l}58 \\
\\
16 \\
26\end{array}$ & $\begin{array}{l}2.99 \\
3.02\end{array}$ & $\begin{array}{l}\text { Artemsia dracunculus } \\
\text { Melilotus officinalis } \\
\text { Bouteloua gracilis } \\
\text { Conyza canadensis } \\
\text { Hedeoma hispida }\end{array}$ & $\begin{array}{r}28 \\
16 \\
8 \\
5 \\
5\end{array}$ \\
\hline
\end{tabular}

$\begin{array}{ccc}\text { Total } & 0-15 & 398 \\ \text { Grazed } & & \\ & 0-2.5 & 4660 \\ & 0-7.5 & 7240 \\ & * 2.5-7.5 & 2580 \\ & 7.5-15 & 510\end{array}$

$4660 \quad 3195-6120$

4990-9490

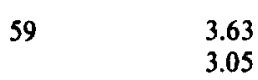

35

1.25

Conyza canadensis

Festuca octoflora

Hedeoma hispida

0-1065

6

Cerastium brachypodum

Plantago patagonica

19

14

13

10

Total $\quad 0-15 \quad 7750$

$\begin{array}{lll}\text { Fresh stockpile } \quad 0-7.5 & 255++ & 48-462\end{array}$

2.32

Andropogon gerardi

A. scoparius

Agrostis scabra

Bouteloua gracilis

Festuca octoflora

2.24 Artemesia frigida

Conyza canadensis

Androsace occidentalis

Bouteloua gracilis

Festuca octoflora

*calculated by difference of $0-2.5$ and $0.75 \mathrm{~cm}$ levels, confidence limits could not be calculated.

+ significantly fewer seeds than equivalent depth level on grazed site $P \leq .05$ ).

++ number of seeds on stockpiles not significantly different from each other but significantly fewer than grazed and ungrazed sites $(0-7.5 \mathrm{~cm} ; P \leq .001)$

\section{Literature Cited}

Barton, L.V. 1962. The germination of weed seeds. Weed Sci. 10:174-182.

Bazzaz, F.A. 1970. Secondary dormancy in the seeds of the common ragweed Ambrosia artemisiifolia. Bull. Torrey Bot. Club 97:302-305.

Bazzaz, F.A. 1979. The physiological ecology of plant succession. Ann. Rev. Ecol. Syst. 10:351-371.

Beauchamp, H., R. Lang, and M. May. 1975. Topsoil as a seed source for reseeding strip mine spoils. Res. J. 90, Agr. Exp. Sta., Univ. of Wyoming.

Best, K.F., J. Looman, and J.B. Campbell. 1971. Prairie grasses. Can. Dept. Agr. Publ. 1413. 239 p

Brenchley, W.E. 1944. Weed control and the dormancy of weed seeds. J. Ministry of Agr., United Kingdom 50:452-455.

Brenchley, W.E., and K. Warington. 1930. The weed seed population of arable soil. I. Numerical estimation of viable seeds and observations on their natural dormancy. J. Ecol. 18:235-272.

Brenchley, W.E., and K. Warington. 1933. The weed seed population of arable soil. II. Influence of crop, soil, and methods of cultivation upon the relative abundance of viable seeds. J. Ecol. 21:103-127.

Brenchley, W.E., and K. Warington. 1936. The weed seed population of arable soil. 111. The re-establishment of weed species after reduction by fallowing. J. Ecol. 24:479-501.

Brenchley, W.E., and K. Warington. 1945. The influence of periodic fallowing on the prevalence of viable weed seeds in arable soil. Ann. Appl. Biol. 32:285-296.

Brophy, L. 1980. Viable seed populations in soils of revegetated North Dakota coal strip mines. Proc. N.D. Acad. Sci. 34:22.

Budd, A.C., W.S. Chepil, and J.L. Doughty. 1954. Germination of weed seeds. III. The influence of crops and fallow on the weed seed population of the soil. Can. J. Agr. Sci. 34:18-27.

Chepil, W.S. 1946. Germination of weed seeds. I. Longevity, periodicity of germination, and vitality of seeds in cultivated soil. J. Agr. Sci. 26:307-349.

Chippindale, H.G., and W.E.J. Milton. 1934. On the viable seeds present in the soil beneath pastures. J. Ecol. 22:508-531.

Connel, J.H., and R.O. Slatyer. 1977. Mechanisms of succession in natural communities and their role in community stability and organization. Amer. Nat. I1I. 1119 . 1144.

Darlington, H.T. 1931. Dr. W.J. Beal's seed viability experiment. Amer. J. Bot. 18:262-265.

Darlington, H.T. 1941. The sixty-year period of Dr. Beal's seed viability experiment. Amer. J. Bot. 28:271-273.

Dunham, R.S., A.H. Larson, and R.G. Robinson. 1947. Weed seedlings. Minn. Agr. Exp. Sta. Bull. 397:1-36.

Dwyer, D.D., and E. Aguirre V. 1978. Plants emerging from soils under three range condition classes of desert grassland. J. Range Manage. 31:209-212.

Gleason, H.A., and A. Cronquist. 1963. Manual of vascular plants of northeastern United States and adjacent Canada. Van Nostrand Reinhold Co., New York. 810 p.
Grime, J.P. 1979. Plant stategies and vegetation processes. John Wiley, Chichester, U.K. 222 p.

Iverson, L.R. 1981 . The role of pioneering species on the recla mation of North Dakota surface mined lands. Ph.D. Dissertation, Univ. of North Dakota, Grand Forks, ND. 202 p.

Iverson, I.R. and M.K. Walli, 1982. Reclamation of coal-mined lands: the role of Kochia scoparia and other pioneers. Rec. and Reveg. Res. 1:123-160.

Jensen, H.A. 1969. Content of buried seeds in arable soil in Denmark and its relation to the weed population. Dansk Botanisk Arkiv 27:1-57.

Johnston, A., S. Smoliak, and P.W. Stringer. 1968. Viable seed populations in Alberta prairie topsoils. Can. J. PI. Sci, 49:75-82.

Lippert, R.D. and H.H. Hopkins. 1950. Study of viable seeds in various habitats in mixed prairie. Kan. Acad. Sci. Trans. 53:355-364.

Major, J., and W.T. Pyott. 1966. Buried, viable seeds in two California bunchgrass sites and their bearing on the definition of a flora. Vegetatio 13:253-282.

McRill, M. and G.R. Sagar. 1973. Earth worms and seeds. Nature 243-482.

Milton, W.E.J. 1948. The buried viable seed content of upland soils in Montgomeryshire. Empire J. Exp. Agr. 16:163-177.

Mortimer, A.M. 1974. Studies of germination and establishment of selected species with special reference to the fate of seeds. Ph.D. thesis, University College of North Wales, Bangor.

Noble, I.R., and R.O. Slatyer. 1980. The use of vital attributes to predict successional changes in plant communities subject to recurrent disturbances. Vegetatio 43:5-21.

Prince, F.S., and A.R. Hodgdon. 1946. Viable seeds in old pasture soils. N.H. Agr. Exp. Sta. Tech. Bull. 89:3-16.

Rabinowitz, D. 1981. Buried viable seeds in a North American tall-grass prairie: the resemblance of their abundance and composition to dispersing seeds. Oikos 36:191195.

Roberts, H.A. 1963. Studies on the weeds of vegetable crops. IIl. Effect of different primary cultivations on the weed seeds in the soil. J. Ecol. 51:83-95.

Roberts, H.A. 1968. The changing population of viable weed seeds in an arable soil. Weed Res. 8:253-256.

Roberts, H.A., and J.E. Neilson. 1981. Changes in the soil seed bank of four long-term crop/herbicide experiments. J. appl. Ecol. 18:661-668.

Robinson, R.G. 1949. Annual weeds, their viable seed population in the soil, and their effect on yields of oats, wheats, and flax. Agron. J. 41:513-518.

Stevens, 0.A. 1963. North Dakota plants. ND Inst. for Regional Studies, Fargo, ND. $324 \mathrm{p}$.

Thompson, K., and J.P. Grime. 1979. Seasonal variation in the seed banks of herbaceous species in ten contrasting habitats. J. Ecol. 67:893-922.

Thurston, J.M. 1960. Dormancy in weed seeds. Pages 69-82 in Harper, J.L. ed. The Biology of Weeds. Blackwell Sci. Pub., London, U.K.

Van Bruggen, T. 1976. The vascular plants of South Dakota. Iowa State Univ. Press, Ames. $538 \mathrm{p}$.

Whitman, W.C. and M.K. Walk. 1975. Grasslands of North Dakota. Pages 53-73 in Wali, M.K. ed. Prairie: a multiple view. Univ. North Dakota Press, Grand Forks, ND. 